\title{
PNPM MANDIRI VS KEMISKINAN DI INDONESIA
}

\section{PNPM MANDIRI VS POVERTY IN INDONESIA}

\author{
Moh. Ilham A. Hamudy \\ Badan Penelitian dan Pengembangan Kementerian Dalam Negeri \\ Jalan Kramat Raya No.132 Jakarta Pusat \\ e-mail: i_hamudy@yahoo.com
}

Diterima:15 Agustus 2013; direvisi: 27 Agustus 2013; disetujui: 18 September 2013

\begin{abstract}
Abstrak
Artikel ini adalah tentang Program Nasional Pemberdayaan Masyarakat (PNPM Mandiri). Artikel ini berusaha mendedahkan PNPM secara makro, seraya menjabarkan beberapa kekurangannya yang kerap menjadi sasaran kritik para pemerhati pemberdayaan masyarakat. PNPM Mandiri, oleh pemerintah dianggap sebagai program jitu guna mengentaskan masyarakat dari kubangan kemiskinan. Tetapi, sayangnya, meski sudah banyak sekali uang digelontorkan untuk mensukseskan program itu, angka kemiskinan di Indonesia tidak mengalami penurunan secara signifikan. Oleh karenanya, PNPM Mandiri perlu ditinjau ulang keberadaannya, baik secara konsep maupun secara implementatif. Artikel ini menawarkan konsep dan pendekatan pemberdayaan dan pengentasan rakyat miskin dengan mengedepankan konsep penghidupan berkelanjutan yang lebih komprehensif.
\end{abstract}

Kata kunci: PNPM Mandiri, Program Pengentasan Rakyat Miskin, dan Penghidupan Berkelanjutan

\begin{abstract}
This article is about the National Program for Community Empowerment (PNPM Mandiri). This article try to exert PNPM macro, as outlines some drawbacks that are often the target of criticism of the observer community empowerment. PNPM Mandiri, the government considered the surefire program to alleviate poverty from the pool. But, unfortunately, though it was a lot of money disbursed to the success of the program, the poverty rate in Indonesia has not experienced significant declines. Therefore, PNPM Mandiri existence should be reviewed, both in concept and in implementation. This article offers the concept and approach to empowerment and poverty of the poor by promoting the concept of sustainable livelihoods is more comprehensive.
\end{abstract}

Keywords: PNPM Mandiri, Poverty, Poverty Alleviation Programs, and Sustainable Livelihoods

\section{INTRODUCTION}

Since Indonesian independence day has been announced in 1945 , poverty has always been a major agenda for development in Indonesia. Governments take various efforts to eradicate poverty. Unfortunately, although the number of poor people has decreased (below 890,000 people over a span from March 2011-March 2012), they are still relatively high, nearly 30 million people.

Central Statistics Agency (BPS) reported that the number of poor or under the poverty line in Indonesia in March 2011 amounted to 30.02 million in March 2012 and to 29.13 million people. That is, the number of poor people fell 0.89 million people, details, during March 2011-2012, the urban poor is reduced 399,500 people (from 11.05 million in March 2011 to 10.65 million in March 2012) and in rural areas reduced by 487000 people (from 18.97 million to 18.48 million).

The number of poor people in Indonesia, has been blamed as a result of an unbalanced development between urban and rural. BPS data showed, as of March 2011, the Poverty Gap Index
(P1) and poverty severity index (P2) in rural areas are higher than in urban areas.

In March 2011, the index of urban P1 is only 1.51, mean while the rural areas reach 2.96 . Significantly the P2 urban and rural reaches of 0.35 0.72 . In other words, the poverty rate in rural areas is worse than in urban areas. Not wrong if the slogan "tuna kapital" attached to the village. The reason is almost 60 percent of the population live in rural areas and 75 percent of them are potential being workers.

\section{DISCUSSION}

\section{Efforts to Eradicate Poverty}

Furthermore, various efforts have been taken by the government to reduce the poverty. For example, the government launched the Integrated Rural Development Program (Pembangunan Desa Terpadu). In 1970s, East Nusa Tenggara (NTT) was choosen as a project leader directed to answer underdevelopment, poverty, and ignorance in the region.

Nevertheless, the program was not very successful, because according to use a centralized and technocratic approach, rural development 
funding fragmented in each ministry and agency (Djoroemana et.al, 2006). In addition, the program requires a considerable investment to accelerate program improvement, especially in infrastructure development (Jamal, 2008).

In the era of ' 90 s to 2000 s, various poverty eradication program re-launched. The programs such as Inpres Desa Tertinggal (IDT), the provision of direct cash assistance (BLT), rice for the poor (Raskin), Kecamatan Development Program, the Urban Poverty Program (P2KP), and other programs continued. However, poverty still exist in the country.

Experts say poverty, various poverty alleviation programs of the community because it was less successful than efforts tend to focus on social aid. Such efforts actually difficult to solve the problems of poverty, because nature does not help to empowerment. In fact, such programs in turn create dependency for the community. In fact, in the distribution of aid can also cause corruption.

Therefore, in 2007, the government, through the assistance of the World Bank loan, ask other programs that were considered more accurate to decrease the poverty. The program was named the PNPM Mandiri (National Program for Community Empowerment). PNPM Mandiri is a program of poverty reduction through community empowerment.

The main objective is to reduce poverty PNPM Mandiri in Indonesia with a community planning process that produces jobs and invest in small-scale infrastructure projects to improve rural and urban development.

Since it was first proclaimed by President Susilo Bambang Yudhoyono, PNPM Mandiri has reached more than 6,000 districts and 70,000 villages in 33 provinces. Contribution from the World Bank in the form of foreign loans specifically PNPM Mandiri Perdesaan untill 2011 reach USD 2,830.1 million or approximately Rp 25.5 trillion.

Even though the numbers are small relative to 2012 revised budget of $\mathrm{Rp} 1343$ trillion, coverage program aimed at almost every village and town, making the PNPM Mandiri as one of the greatest poverty reduction programs in Indonesia.

\section{Principal Program of PNPM Mandiri}

Within five years, the PNPM Mandiri has done five main programs. First, the PNPM Mandiri Perdesaan, the community empowerment program in order to accelerate poverty reduction and expansion of employment opportunities in rural areas.

The program has carried out further encourage efforts to improve the quality of life, well-being and independence of people in rural areas. PNPM Mandiri Perdesaan has become an integral part of the PNPM Mandiri and has done since 1998 through Program Pengembangan Kecamatan (PPK).
Second, PNPM Mandiri Perkotaan, a program to reduce poverty and accelerate the expansion of employment opportunities in urban areas. The program has carried out further encourage efforts to improve the quality of life, well-being and independence of people in urban areas.

PNPM Mandiri Perkotaan is an integral part of the PNPM Mandiri. It has done since 1999 as the Urban Poverty Program (P2KP) in order to build community self-government and local governments to reduce poverty in a sustainable manner.

Third, PNPM Mandiri Pengembangan Infrastruktur Perdesaan, namely empowerment mechanisms used to improve the welfare of rural communities through improved access of the poor to basic rural infrastructure services.

Fourth, PNPM Mandiri DTK (Daerah Tertinggal dan Khusus), a program of empowerment that comes from P2DTK Program (Program Percepatan Pembangunan Daerah Tertinggal dan Khusus), which aims to help local governments accelerate the socio-economic recovery and growth in lagging regions and special. The program is given to disadvantaged areas and those with social conflict and natural disasters.

Last, PNPM Mandiri Pengembangan Infrastruktur Sosial Ekonomi Wilayah (PISEW), a program of community empowerment centers to integrate economic growth with the surrounding area.

\section{Community Empowerment}

In implementing the five main programs, the PNPM Mandiri program emphasizing community empowerment. Community empowerment in question is an effort to increase the capacity of the community, both individually and collectively, in order to solve problems to improve the quality of life, self-reliance and sustainable prosperity.

Diverse forms of empowerment. First, the development community. This community development component includes a series of activities to build critical awareness and independence of people consisting of mapping potential, problems and needs of the community, participatory planning, organizing, resource utilization, monitoring, and maintenance of the results that have been achieved.

As a supporter, provided funds community learning activities, volunteer development and community assistance operations, and facilitators, capacity building, mediation and advocacy. The role of the facilitator, especially at the beginning of empowerment, while community volunteers are the main driving force of the community in the region.

Second, Bantuan Langsung Masyarakat (BLM). BLM is a self-supporting fund stimulant given to community groups to fund some of the activities planned by the community in order to improve welfare, especially the poor. 
Third, governance and capacity building of local actors. Its components are a series of capacity building activities of local government and local actors/other concerned groups in order to create favorable conditions and synergies for people, especially the poor. Core activities can include seminars, training, workshops, field visits were conducted selectively, and so on.

Fourth, management and development assistance programs. Forms of empowerment through the provision of management activities such as management consultants, quality control, evaluation, and program development

In implementing the four empowerment program, conducted entirely by purely self-managed society based on the principles of autonomy and facilitated by the government, assisted by a facilitator or consultant. Carried out after the implementation phase of the planning process has been completed and a decision is made about the allocation of funding activities.

Implementation activities include the selection and determination of the management team activities, disbursement or application of funds, manpower deployment, procurement of goods/services, and the implementation of the proposed activities. Personnel management team selected activities and established by the people, responsible for the realization of the physical, financial, and administrative activities/work carried out as planned.

When conducting a self-managed, when needed goods/services in the form of materials, tools, and experts (consultants) individuals who can not provide or can't be done alone by the public, the relevant technical department can help the community to meet these needs.

\section{Critics on the PNPM Mandiri}

Although considered accurate, and thus continued until 2014, PNPM Mandiri is criticized, both by the general public, NGOs, as well as observers of poverty in the country. First, the PNPM Mandiri budget allocated for the construction of more physical than social programs. Approximately 70 percent of the budget it dominates the overall physical program PNPM program. Unfortunately, today there are no reports of PNPM Mandiri contribution to reducing poverty in Indonesia.

This is consistent with research by NGOs like GAPRI, IRE, NTB Conception, INFID and FIK presented in a seminar held earlier in July 2012. According to them PNPM Mandiri has not responded to the problem of poverty. Although one of the main principles of PNPM Mandiri is human development but the findings showed minimal aspects of community do PNPM Mandiri compared to physical development that seems massive.

Second, BLM, one of which poured in savings and credit program for women (SPP), claimed to have women alleviate poverty through the provision of revolving funds, the fact that credit is given to people who already have a business, not a really poor (compare to Kabir M.S et.al. 2012). Worse yet, the credit is only an indicator of success rather than the return on savings and loan business success.

Third, the approach adopted by the PNPM Mandiri Bank through the concept of Community Driven Development (CDD) or community-based development program was allegedly internalization Neo-Liberal approach through community.

Responses Tania Murray Li of the University of Toronto in early July 2012 at a seminar stressed PNPM Mandiri (Tifa and Infid, 2012) emphasizes competition in the filing system proposal, using procurement tenders. According to Tania, the basic nature of the market that free competition was introduced at the level of the bottom of the village.

PNPM Mandiri accused does not have a direct economic purpose, but want the social transformation in society so adaptive to the promarket culture. In fact, in free competition as it is not all people have the knowledge and access to the same information. The system only provides benefits to people who have a good knowledge and close relationship with program facilitators.

\section{CLOSING}

\section{Sustainable Livelihoods}

Therefore, PNPM Mandiri should be promptly evaluated. PNPM Mandiri failed welfare of the poor in the village. There needs to be a new approach to eradicate poverty. According to Sutoro (2005) there is an alternative approach that can be offered. An alternative is the sustainable rural community livelihood approach (see too Yaro, 2006). Such an approach brings rural community livelihoods from a condition of susceptibility to sustainability by developing the assets and capabilities they possess and enabling them to be transformed, recognising the dynamics that exist.

Community livelihood is the capability for survival that is possessed by all, both materially and socially, that is realised through a variety of activities performed to fulfil the needs of life. A community livelihood approach looks at the complexity of individual and community assets and is concerned with the dynamics of transformation.

As one individual or group may respond more quickly than others, it is important to have a variety of activities based on individual character empowerment. The approach builds individual and group capacity to develop local potential so they are able to overcome their own problems and indeed use them as a means of achieving their goals (see Neely, et.al 2004). A sustainable livelihood approach transforms communities by building local capacity so that their living assets can be transformed by it. 
The basic concept of sustainable livelihood development (Sutoro, 2005) is as follows:

1) People are the focus of all development activities (people-centred). All understanding, analysis, planning and change within the process comes from the people themselves.

2) A holistic approach begins with the community's understanding and priorities. All factors, be they hindrances or opportunities, should be understood within the context of the community's knowledge and ability, so that eventually communities can develop their own solutions.

3) Bearing in mind that life is dynamic, we can only ever get a temporary snapshot of any given situation; therefore, sustainable livelihood development needs to be aware of, and adjust to, change, making it important to develop participative monitoring and shared learning among community and other stakeholders.

4) This approach is more concerned with capacity building than needs analysis. Building on strengths means there is an acknowledgement of every individual's capability to develop themselves, and through strengthening social networks problems can be solved (either individually or collectively), obstacles can be overcome and the potential to achieve goals can be realised.

5) There is a link between the macro and the micro in the process of change and development. The approach endeavours to become a bridge in the gap between theory and practice and between macro policy and micro activity. It is essential that the individual and the community have an understanding as to what is happening in the macro context that is influencing their lives. Similarly, for those influencing the macro environment, such as policy makers, it is important that they understand issues and events at the community level.

6) This approach demonstrates the tangibility and sustainability of a given process working as part of a cycle. This cycle should be continuous and experience no upset that leads to its deterioration or collapse. The result should be a transformation from susceptibility to sustainable improvement.

\section{REFERENCES}

Djoeroemana, et.al. 2006. An overview of environmental, sociocultural, economic and political aspects of rural development in East Nusa Tenggara. Proceedings of a workshop to identify sustainable rural livelihoods, held in Kupang, Indonesia, 5-7 April. ACIAR Proceedings No. 126

Jamal, Erizal. 2008. Kajian Kritis terhadap Pelaksanaan Pembangunan Perdesaan di
Indonesia. In Forum Penelitian Agro Ekonomi. Volume 26 No 2. December, page 92-102

Kabir, M.S, et.al. 2012. Impact of Small Entrepreneurship on Sustainable Livelihood Assets of Rural Poor Women in Bangladesh. International Journal of Economics and Finance. Volume. 4, No. 3; March. Canadian Center of Science and Education: Canada

Neely, Constance et.al. 2004. Do Sustainable Livelihoods Approaches Have a Positive Impact on the Rural Poor? Livelihood Support Programme 16 Working Paper. Food And Agriculture Organization Of The United Nations

Sutoro, Eko. 2005. Manifesto Pembaharuan Desa. APMD Press: Yogyakarta

Tifa and Infid. 2012. PNPM Mandiri: Antara Retorika dan Realita. Proceeding of national seminar, held in Jakarta, Indonesia, 4 July

Yaro, Joseph Awetori. 2006. Is deagrarianisation real? A study of livelihood activities in rural northern Ghana. Journal of Modern African Studies, 44, 1, pp. 125-156. Cambridge University Press: UK 